\title{
Obras desconhecidas de Miguelzinho Dutra
}

\author{
Ruth Sprung Tarasantchi
}

Depto de Artes Plásticas da ECA/USP

Foi em 1981 que o Museu de Arte de São Paulo (MASP), juntamente com o Museu Paulista, mostraram uma interessante e importante exposição de aquarelas de Miguelzinho Dutra. Na ocasião, foi editado o catálogo, apresentado por Pietro Maria Bardi, que tinha ficado entusiasmado ao conhecer a obra deste importante personagem paulista do século XIX. Não podemos chamá-lo só de pintor, pois foi muito mais que isto, como veremos mais adiante. $\bigcirc$ livro apresenta as aquarelas que hoje fazem parte do acervo do Museu Paulista, mas vieram de ltu. Como se trata de obras executadas em papel frágil e são aquareladas, elas raramente são expostas. Sendo assim, o catálogo é a única referência que temos da obra deste artista. Estão reproduzidos nele projetos de altares, túmulos, talhas, alegorias, arcos comemorativos, retratos de pessoas que viveram no início do século XIX, tanto personalidades como tipos curiosos. Igrejas e conventos de Piracicaba, Itu e São Paulo, vistas de ltu e cascatas são importantes documentos destas cidades e seus entornos e também da lavoura canavieira que estava no auge.

Mário de Andrade, que conheceu as aquarelas de Miguelzinho, apesar do entusiasmo da descoberta achou o trabalho "imperfeito na técnica da pintura", mas de "enorme importância iconográfica", mesmo considerando-as "francamente incorretas como desenho e colorido".

Já Bardi não considera Miguelzinho um primitivo e sim um espontâneo, ingênuo não. Para ele, o artista "queria imitar a natureza" e por este motivo considera suas aquarelas "deliciosas e caseiras".

Seria realista, não verista, reduzindo a realidade à sua percepção nua e crua, um vedutista observador minucioso.

Foi em 1937 que os irmãos Dutra fizeram uma grande mostra de arte dos artistas da família no salão das Arcadas. Havia as obras do pai, Joaquim Dutra, de seus filhos José Dutra, Alípio Dutra, Arquimedes Dutra e 
Antonio Pádua Dutra, e do bisavô, Miguelzinho Dutra, do qual mostraram três aquarelas. Destas, hoje, não sabemos o paradeiro e esperamos que apareçam um dia.

Anos mais tarde, em 1972, Arquimedes defendeu tese de doutorado na ESALQ, Escola Superior de Agricultura Luiz de Queiroz, em Piracicaba. Estudou os artistas piracicabanos e, em especial, a obra do bisavô Miguel Arcanjo Benício de Assunção Dutra, o Miguelzinho. Como a tese não foi publicada, poucos tiveram acesso aos dados do artista.

Em recente livro da família Dutra, de autoria de Augusto Velloso, encontramos reproduzidos vários documentos de valor histórico.

Miguelzinho nasceu em Itu, a 15 de agosto de 1810, e morreu em Piracicaba a 22 de abril de 1875. Foi músico, excelente organista, tinha a capacidade de produzir instrumentos e tocá-los. Estudou com os padres carmelitas, com quem aprendeu latim e teologia. Foi mestre-de-obras, fez trabalhos de arquitetura em igrejas e esculpiu imagens.

Este homem de tantas qualidades e interesses foi autodidata na pintura, descobriu o uso da aquarela por si mesmo. Vivia no interior e não tinha acesso aos produtos de pintura, por isso, sua paleta era reduzida. Usava sempre o azul para as árvores, matas e águas; tons ocres e castanhos para as construções e outros detalhes. Raramente aparecia o vermelho e, mais dificilmente, o verde. Como ele mesmo preparava suas tintas, é de admirar seu bom estado e o fato de não terem perdido a intensidade da cor.

Em conversa com a amiga Maria Cristina Paranhos Rio Branco, tomei conhecimento de uma coleção particular com 14 aquarelas de Miguelzinho, totalmente desconhecidas do público e dos estudiosos da arte. Perguntei aos familiares do artista se tinham conhecimento destas obras e soube que eles não as conheciam, apesar de terem notícia da existência delas. Colocada em contato com os donos, pude conhecer as obras e vê-las. Por coincidência, elas foram expostas em agosto por Max Perlingueiro, que as pediu emprestadas aos seus donos para valorizar o Salão dos Antiquários de São Paulo, que estava festejando o décimo ano. Foi este o motivo de o público poder apreciá-las por uma semana. De volta ao colecionador, este permitiu que fossem publicadas para serem vistas e estudadas futuramente.

As paisagens desta nova coleção representam vistas e recantos do Estado de São Paulo. $O$ papel é o mesmo das que se encontram no Museu Paulista, e estão em muito bom estado, com algumas pequenas perdas laterais. Em algumas, o artista usou o papel dos dois lados.

Miguelzinho viajou pelo interior do Estado de São Paulo e pintou estes registros, nos quais temos um importante documento das primeiras décadas do século XIX, com destaque do tipo das construções nas nossas vilas e campos vizinhos.

A vista mais importante é a que nos mostra ltu. Estão em evidência a igreja, o casario, ruas de terra e pequenas chácaras. Existe outra versão desta, só que pintada a óleo. Faltam nela parte da paisagem da direita e o lado esquerdo tem o casario mais detalhado. Comparando as duas, a aquarelada é mais solta, mais espontânea.

Em outras duas vistas, de Guaratinguetá e Mogi das Cruzes, vemos as vilas de longe, aparecendo o casario e a vegetação, na de Guaratinguetá, e as 
colinas atrás, na de Mogi. No verso da de Mogi está pintada uma pequena vista com igreja e arvoredo.

Em outra vista de Galhambá, pintada frente e verso, temos, de um lado, construções feitas com troncos que sustentam um telhado de palha. Parece tratar-se de um dos locais de descanso que havia nas estradas. Aparece uma negra cozinhando com uma panela dependurada em um tripé com o fogo aceso embaixo. Homens descansam e caixas e sacos estão espalhados no local. Do outro lado do papel estão pintadas casas de pau-a-pique, telhado de palha, bananeiras, a casa simples do caboclo.

Na aquarela de luru-Mirim, uma casa de porta e três janelas, telhado simples e, na frente, um rio com pedras ladeado pela floresta. Na aquarela de Taubaté aparece a igreja, casario e a vila esparramando-se pelas colinas.

Em outro registro da região, há no centro uma construção de muitas janelas com alpendre sustentado por estranhas - para o local e época - colunas neoclássicas. A casa está apoiada em uma superfície plana e rochosa. Do outro lado do papel, encontramos construções baixas cobertas com telhas e pessoas, animais e carroças.

Ele pintou Pindamonhangaba vista de longe, e aí temos suas casas e íngremes estradas de terra. Em outra aquarela fixou fazendas, plantações e colinas.

Miguelzinho, ao viajar, levava as aquarelas, pintava o que via, sentindo necessidade de reproduzir as paisagens que o inspiravam, usando uma pincelada pequena. Quando necessitava de um trecho com mais intensidade, voltava várias vezes com a tinta para o mesmo lugar, sem se preocupar em perder a transparência da aquarela. Para os aquarelistas esta qualidade é fundamental, mas provavelmente ele nem tinha conhecimento deste fato. Muitas vezes suas figuras humanas foram simplificadas, chegando a parecer bonecos. Mas são seus trajes típicos, ou seus afazeres que nos ensinarão muito sobre os costumes do período.

Como o artista fez trabalhos de arquitetura, fica aparente em algumas aquarelas a linha reta, sente-se o emprego da régua. Estas características são mais evidentes nos arcos que projetou para ltu, por ocasião da visita de D. Pedro II em 1846. Reproduziu ainda o chafariz do Piques em São Paulo, em 1847, alguns túmulos, o convento da Luz, em São Paulo, a igreja do Senhor de Bom Jesus de Itu ( 184 1), o colégio do Padre Campos, também de Itu (1 847), a igreja do Carmo de São Paulo e a catedral Imperial de São Paulo, de 1847, mais tarde demolida.

Felizmente estas aquarelas estão hoje preservadas pelo Museu Paulista. Quando o pintor se afasta das construções e vê as vilas a alguma distância, aparece uma pintura ingênua, simplificada, mas com uma poesia que nos encanta. A diminuta paleta de cores faz com que seu trabalho fique personalíssimo, logo reconhecido pelos azuis com que trata a vegetação e os castanhos do resto da paisagem.

Poucos foram os artistas que deixaram registros dos meados do século XIX do nosso Estado. Seu valor documental e artístico são motivos que aumentam o valor da obra de Miguelzinho. Com o aparecimento de obras desconhecidas, como é o caso destas, o interesse se redobra especialmente para os historiadores de arte e também para os que se interessam em saber sobre a evolução da região. 


\section{REFERÊNCIAS}

BARDI, Pietro Maria. Miguel Dutra, o poliédrico artista paulistano. São Paulo: Museu de Arte de São Paulo Assis Chateaubriand, 1981.

TARASANTCHI, Ruth Sprung. Pintores paisagistas. São Paulo. 1890-1920. São Paulo: Edusp/Imesp, 2002.

VELLOSO,Augusto Carlos Ferreira. Os artistas Dutra. São Paulo: Imesp/Sociarte, 2000.

Artigo apresentado em 10/2003. 


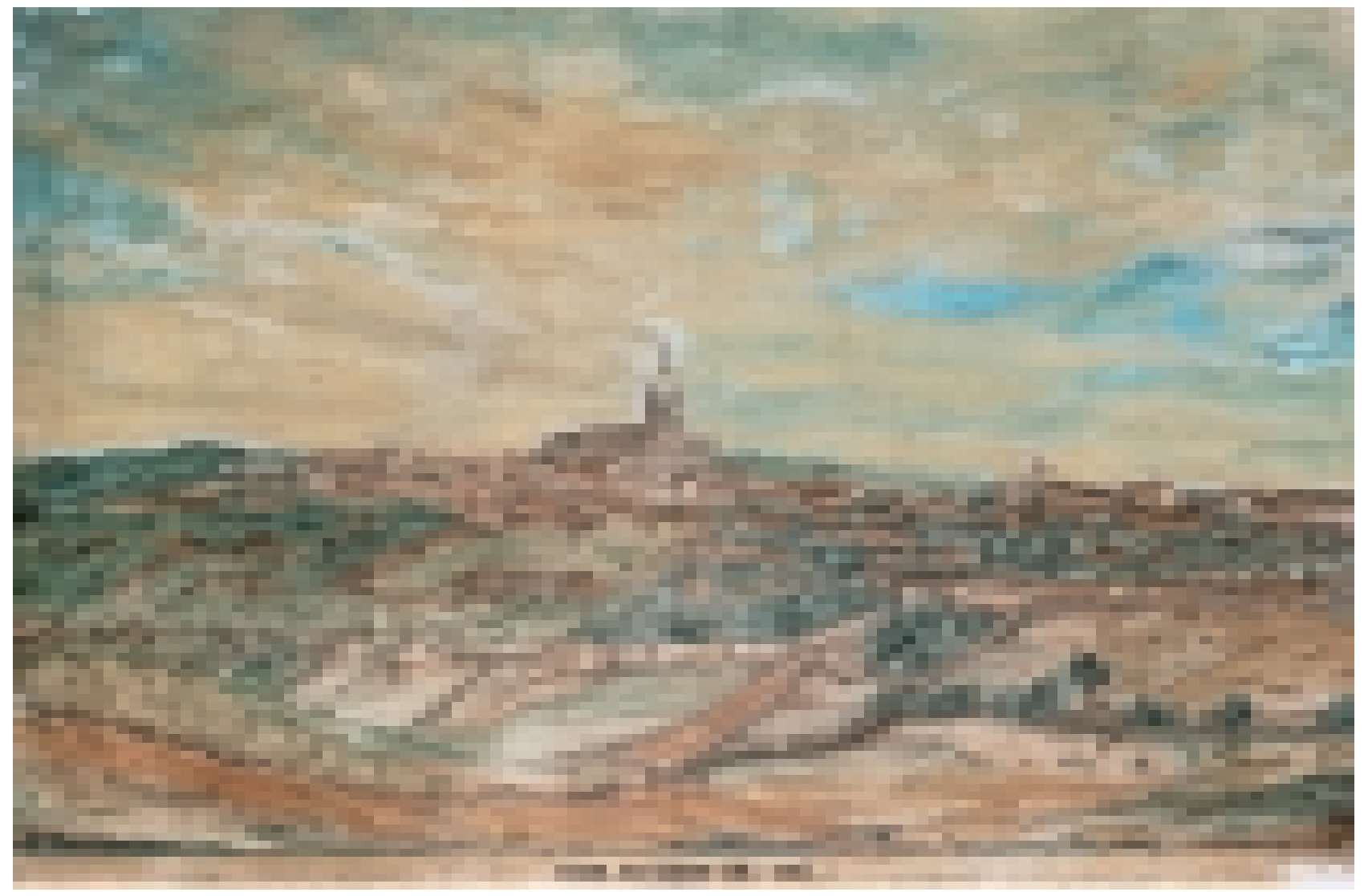

FIGURA 1 - Vista de ltu. Aquarela de Miguelzinho Dutra, 74,5 x 49 cm. Coleção particular. 


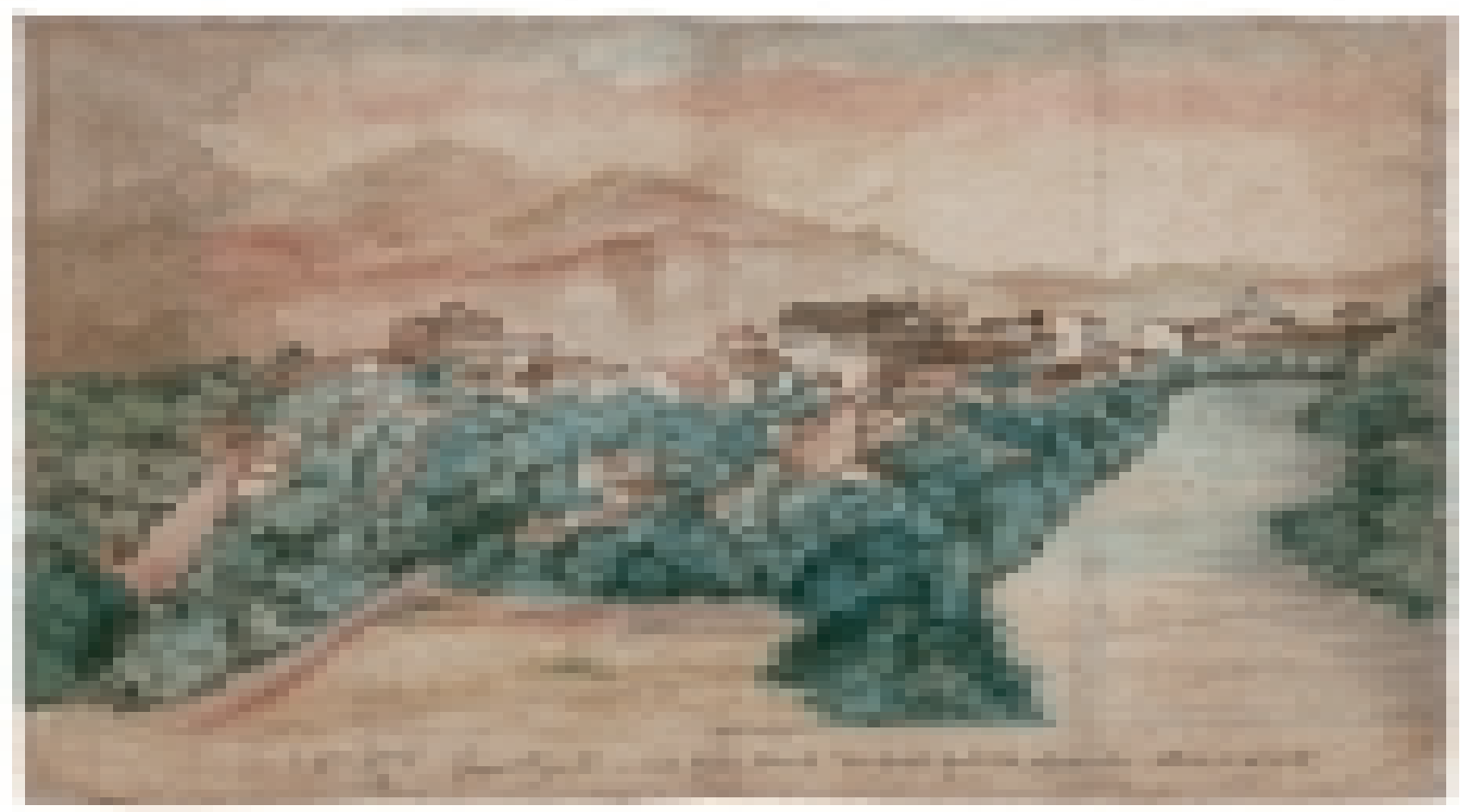




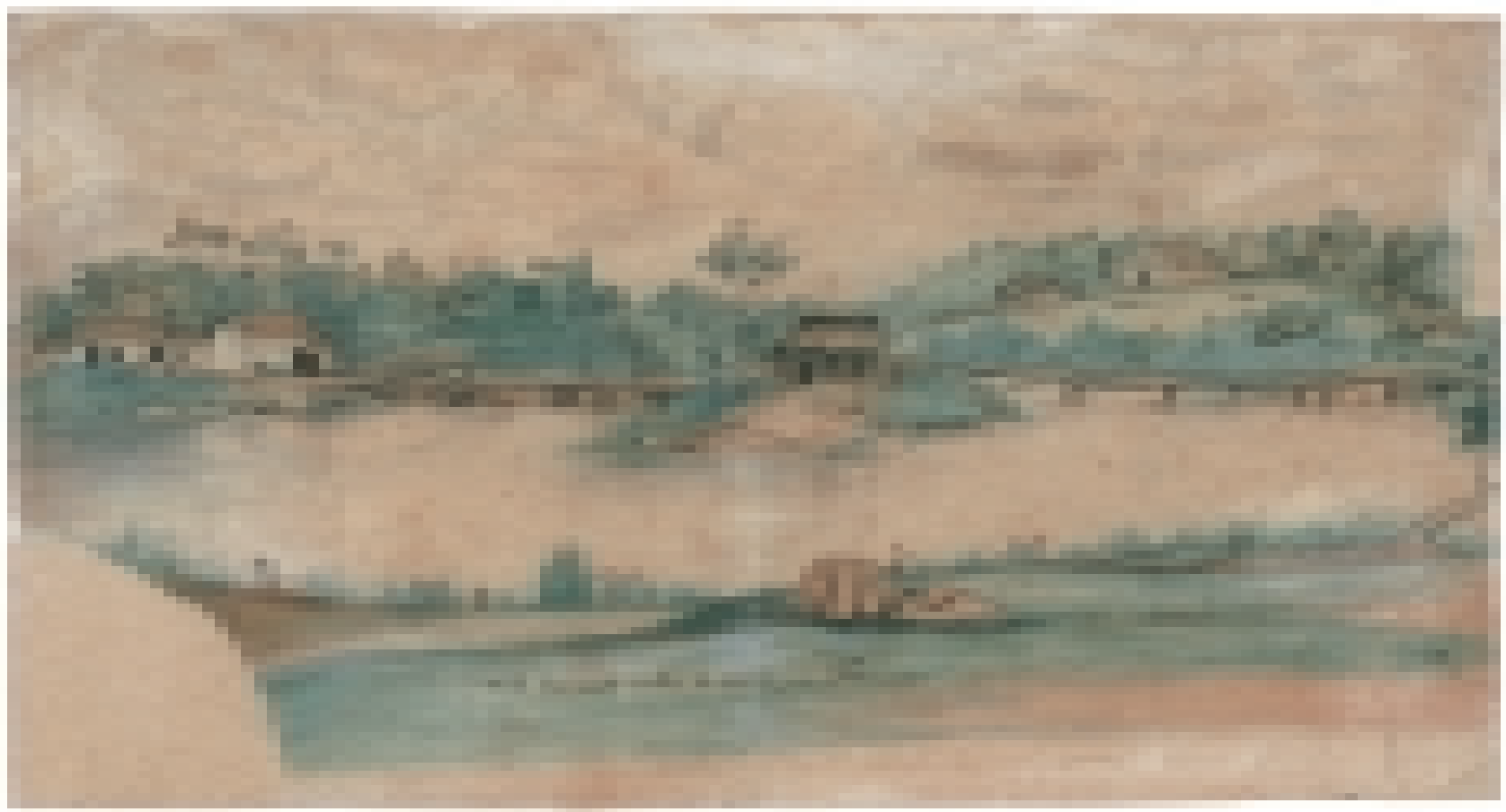

FIGURA 3 - Vista Ponte Velha ltu. Aquarela de Miguelzinho Dutra, $37 \times 20 \mathrm{~cm}$. Coleção particular. 


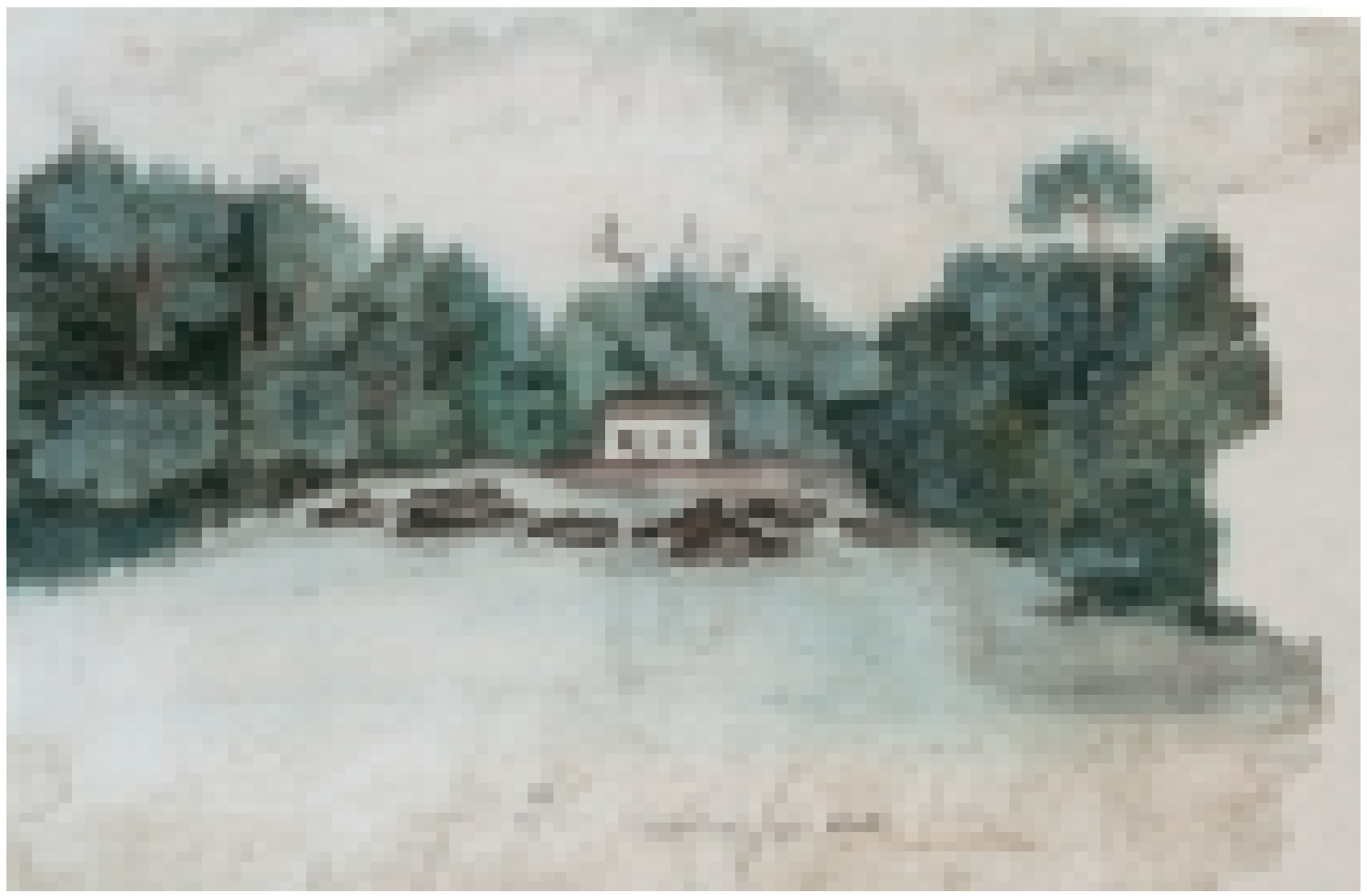




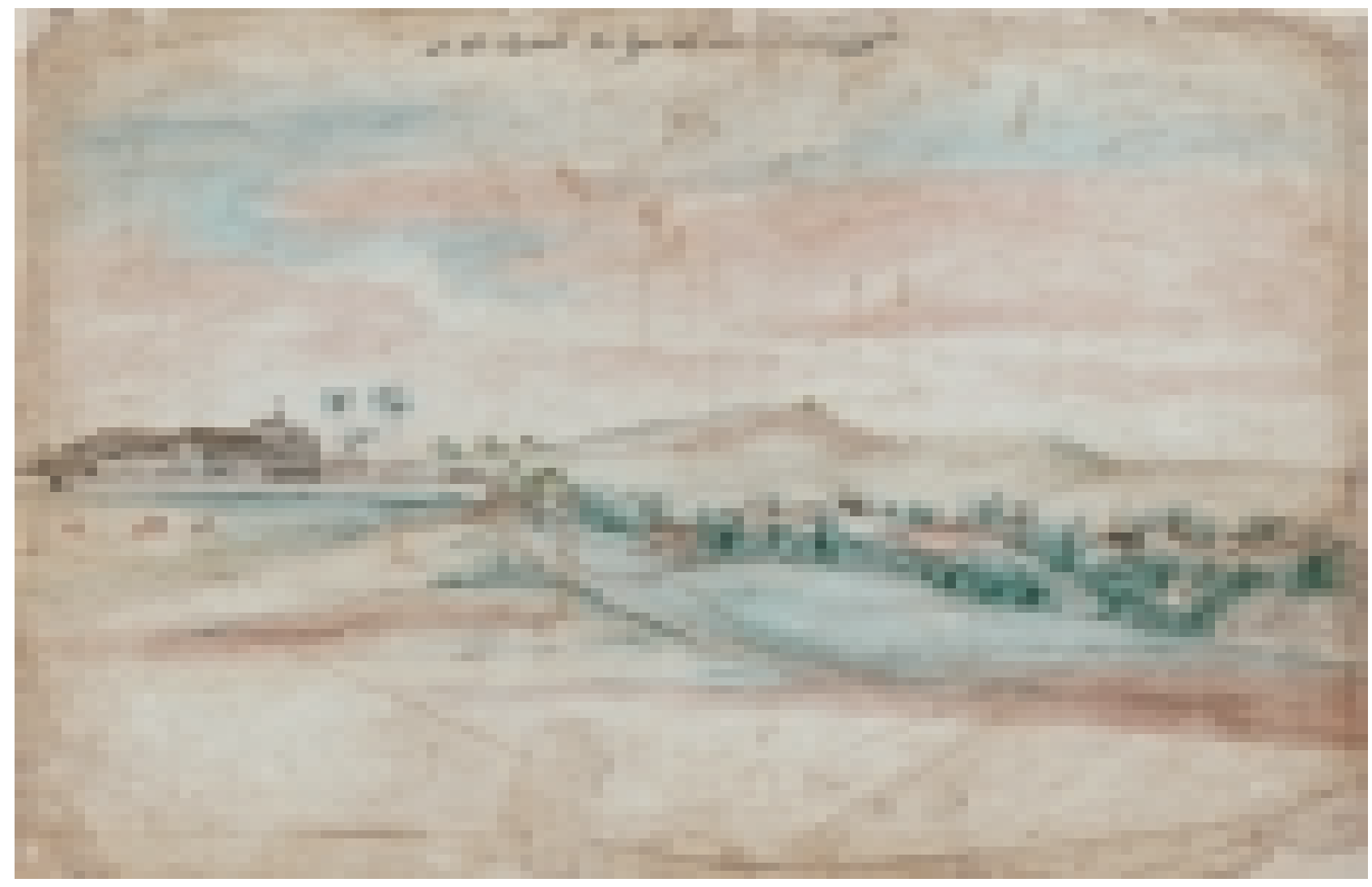

FIGURA 5 - Taubaté. Aquarela de Miguelzinho Dutra, 41,5 × $27 \mathrm{~cm}$. Coleção particular. 


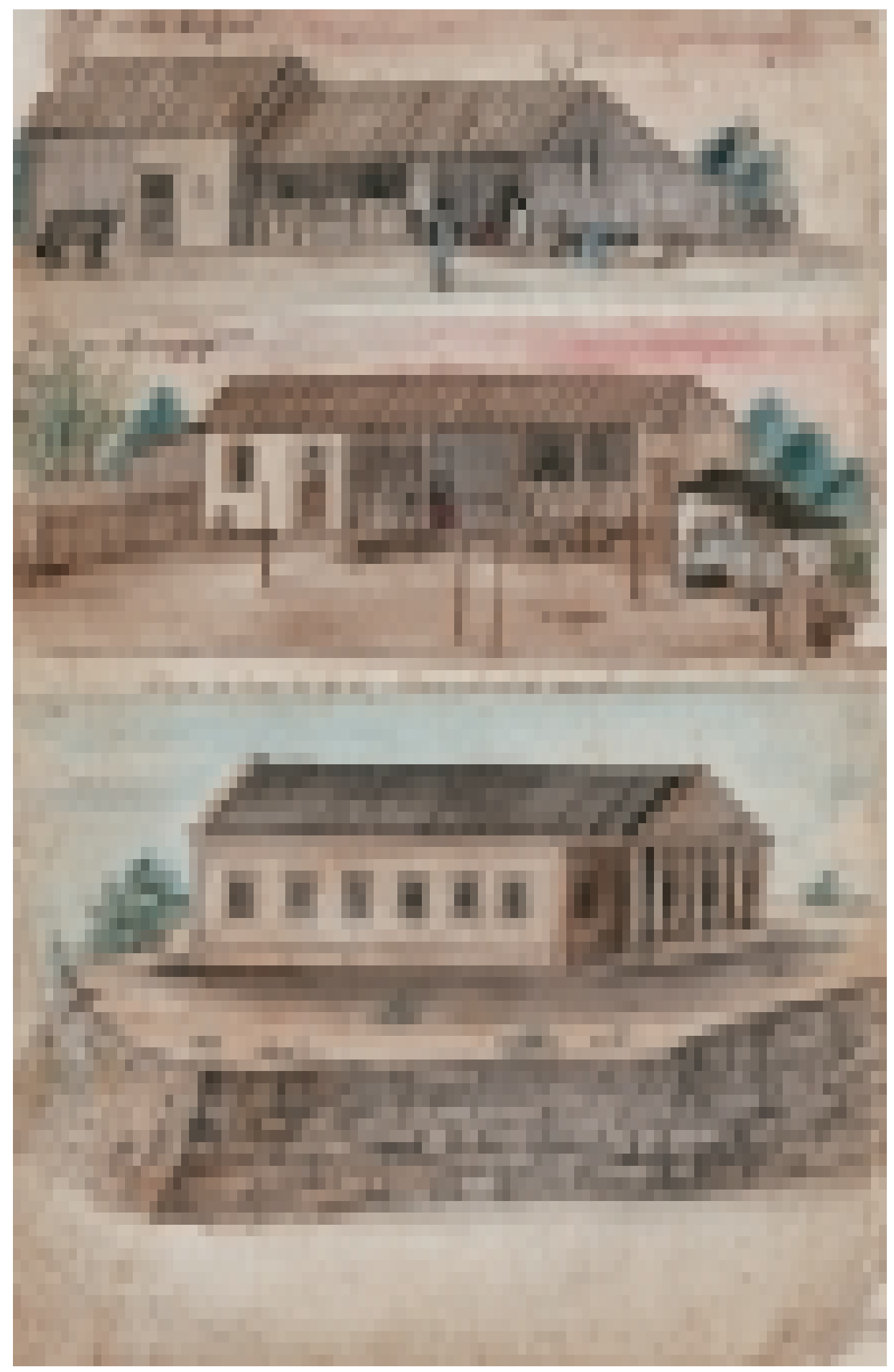

FIGURA 6 - Verso de Taubaté. Aquarela de Miguelzinho Dutra, 41,5 × $27 \mathrm{~cm}$. Coleção particular. 


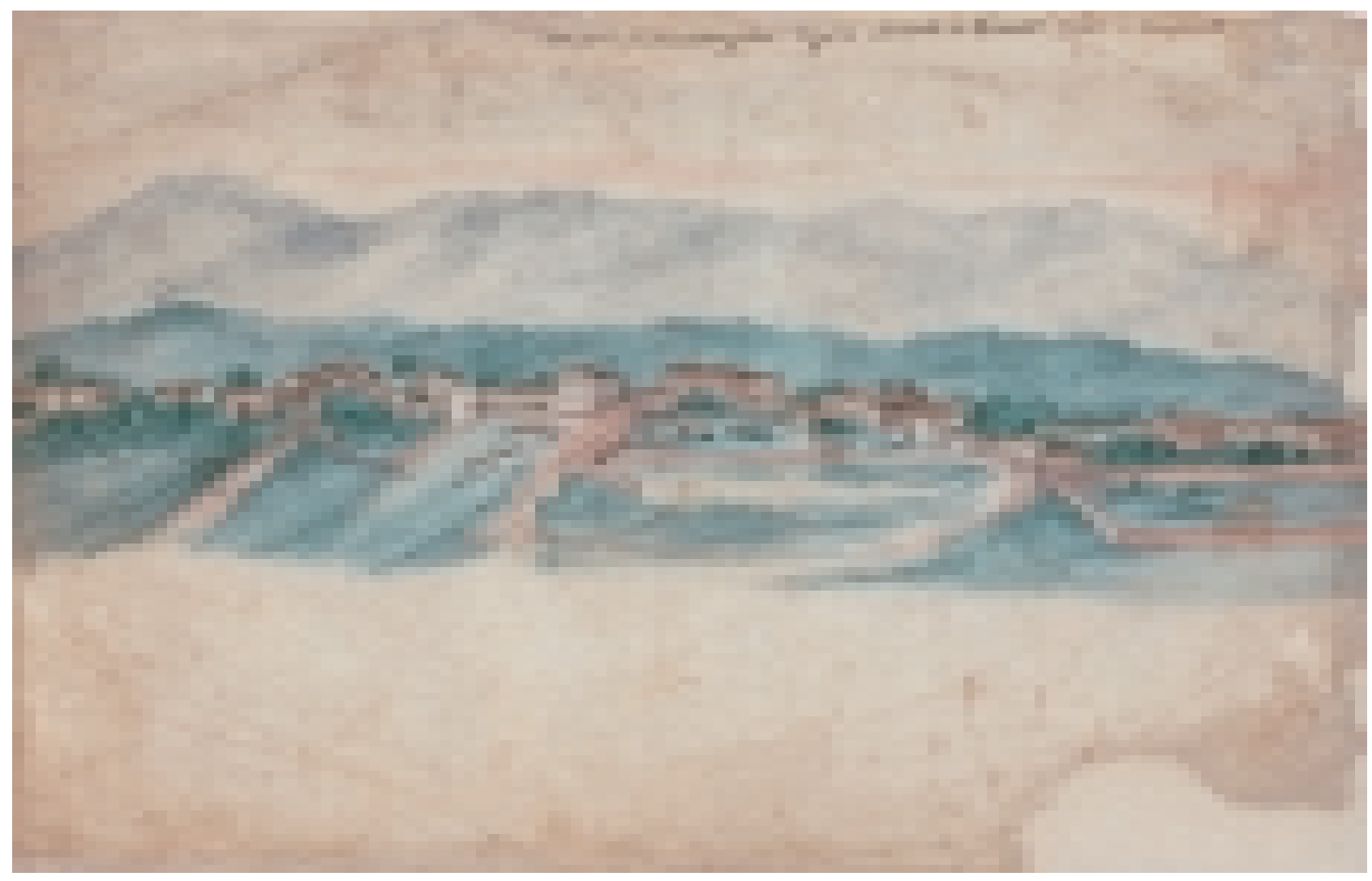




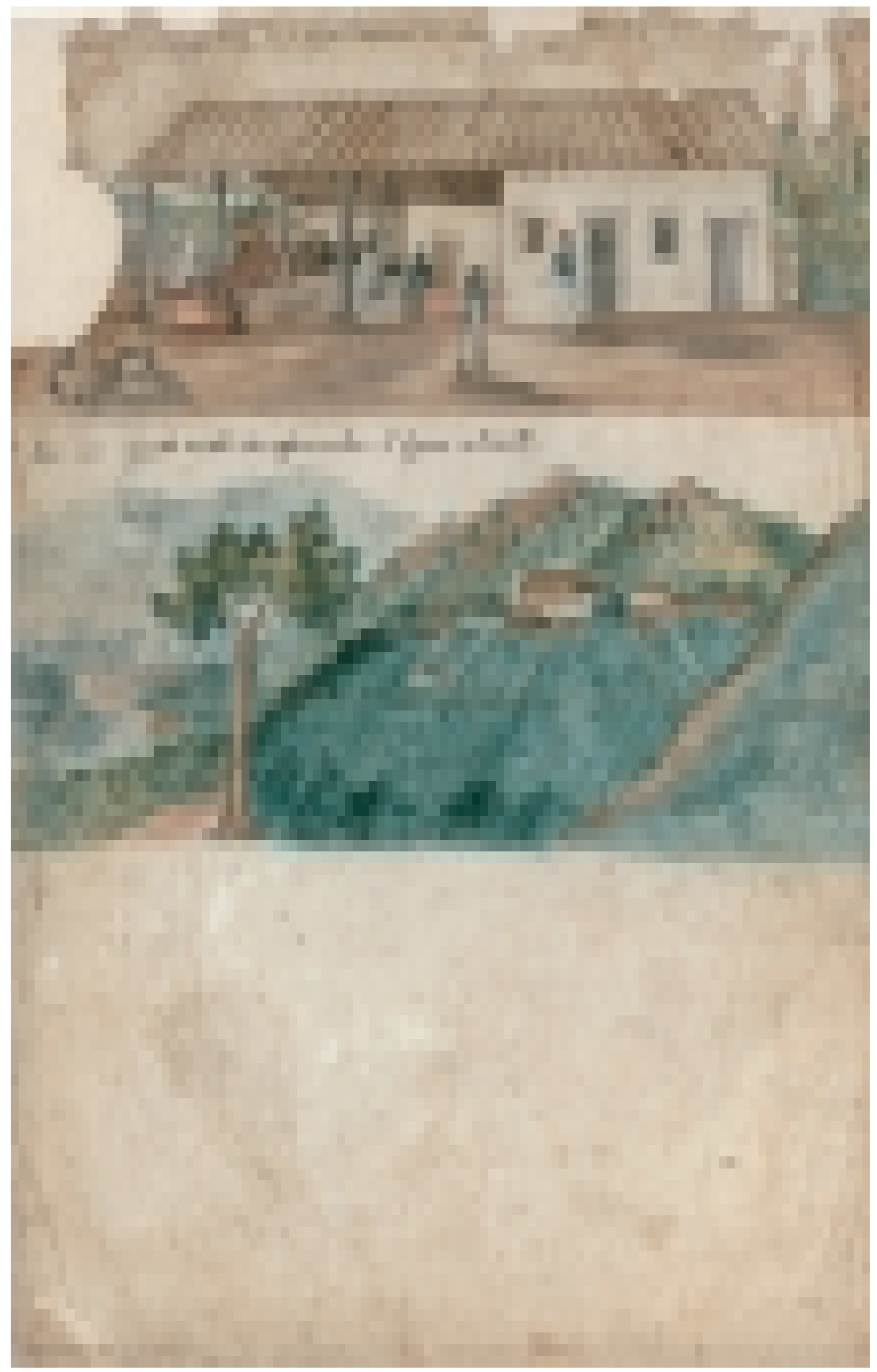

FIGURA 8 - Água Preta e Capella Aparecida (verso de Pindamonhangaba). Aquarela de Miguelzinho Dutra, 41,5 × 27. Coleção particular. 


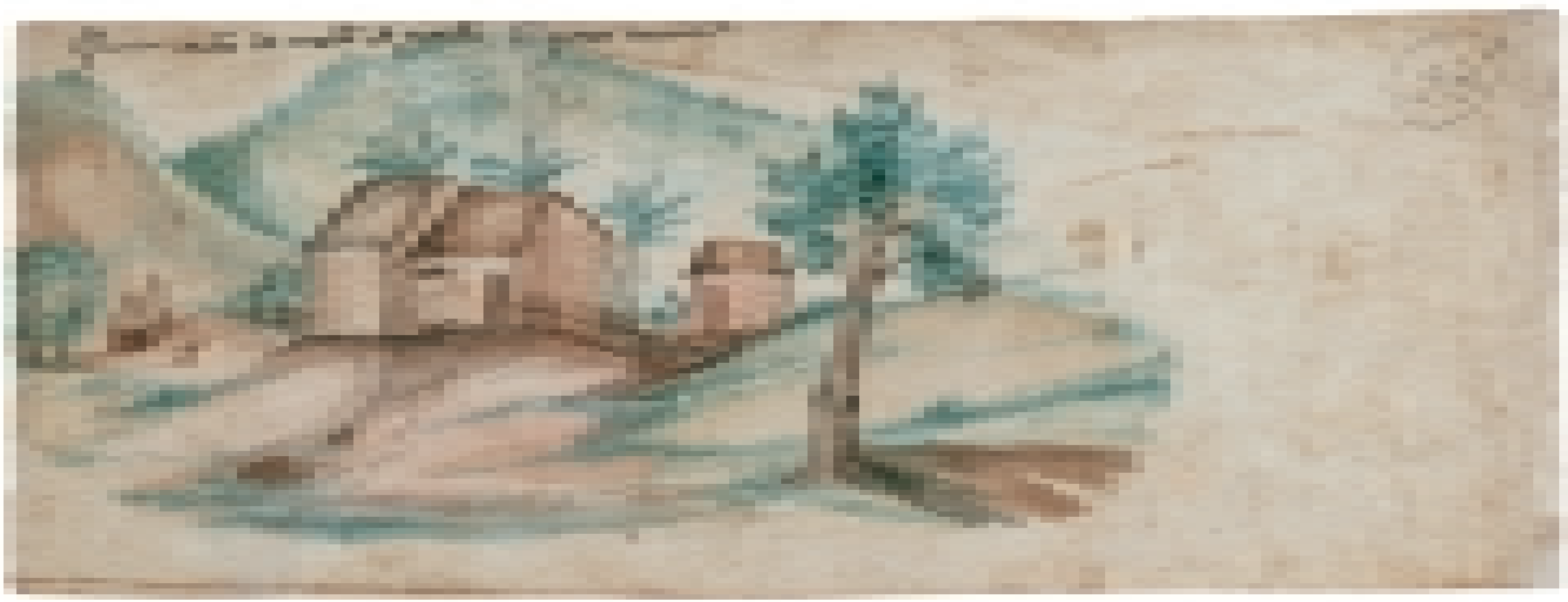

FIGURA 9 - Povoado. Aquarela de Miguelzinho Dutra, $26,5 \times 10 \mathrm{~cm}$. Coleção particular.

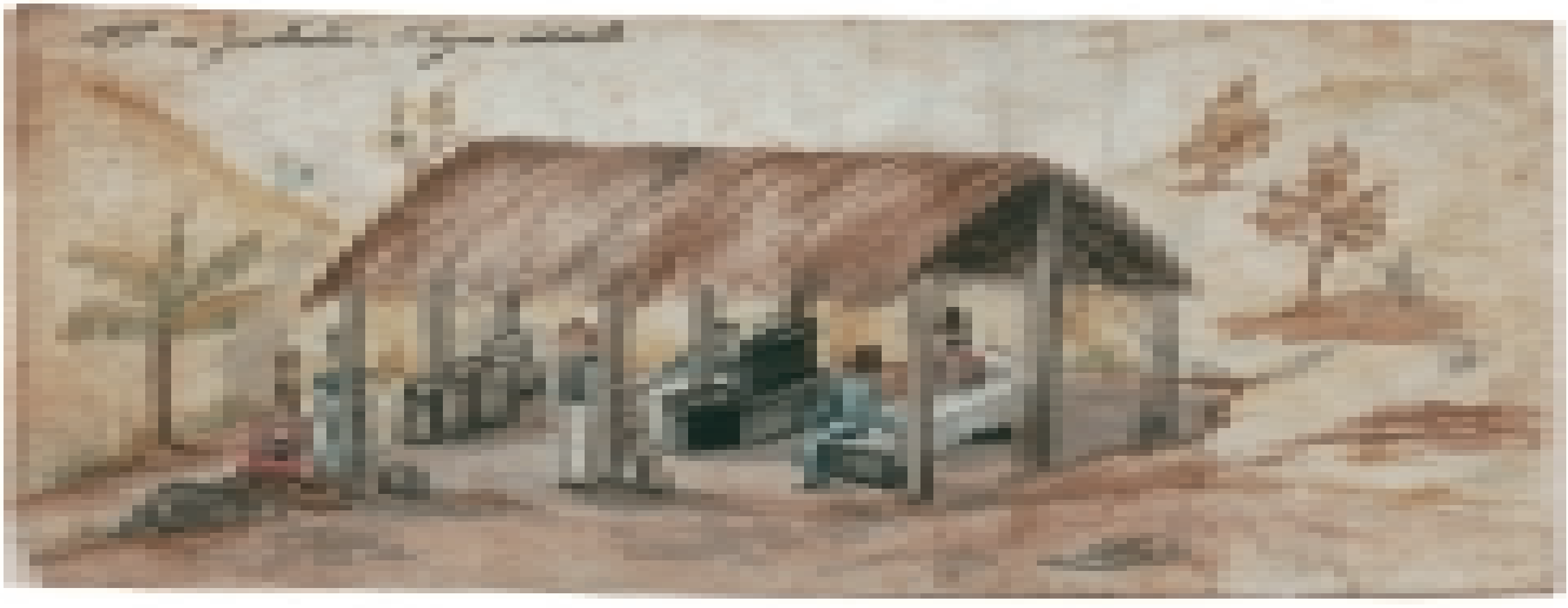





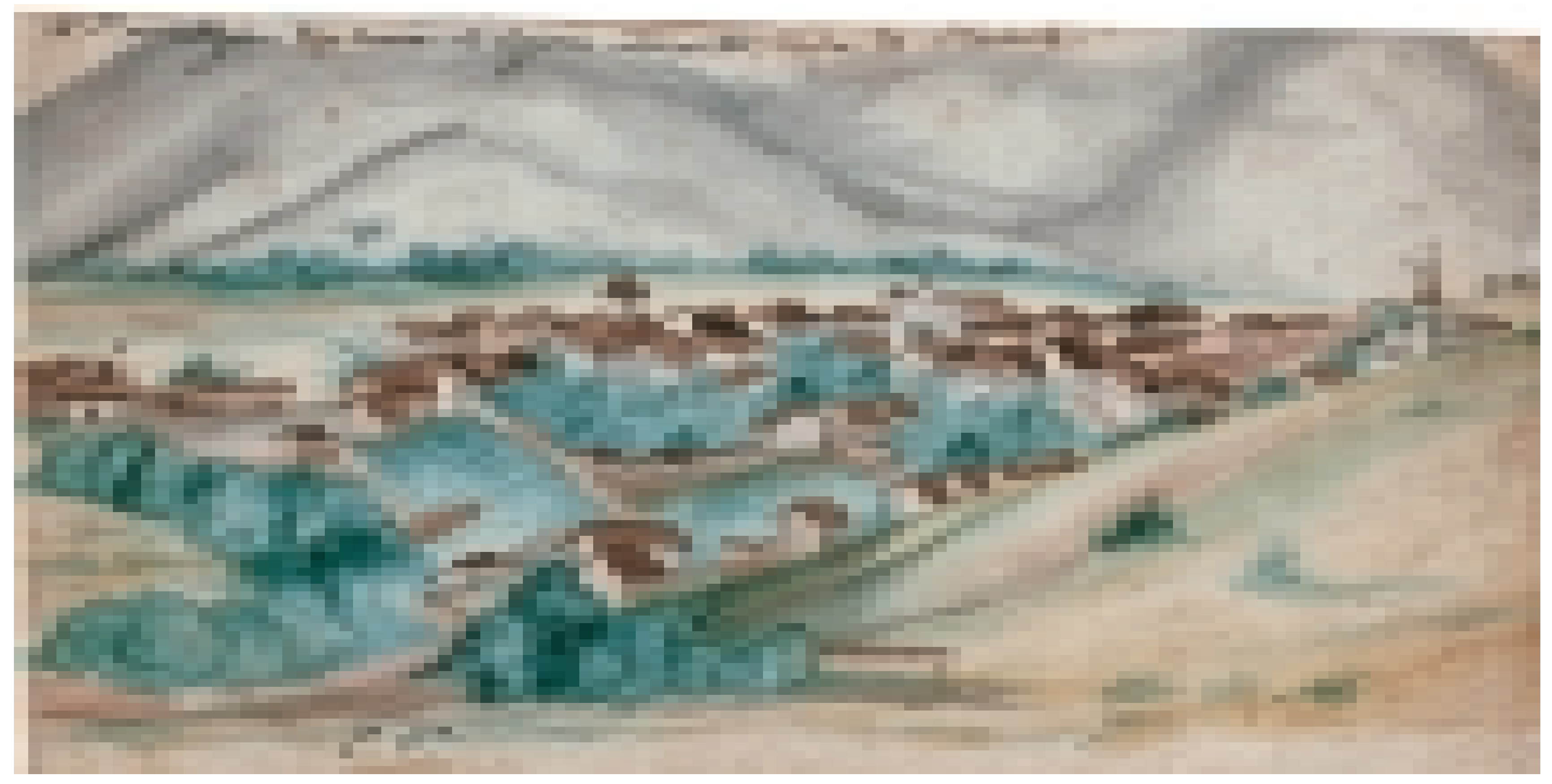

FIGURA 11 - Mogi das Cruzes. Aquarela de Miguelzinho Dutra, 26,5 × $10 \mathrm{~cm}$. Coleção particular. 



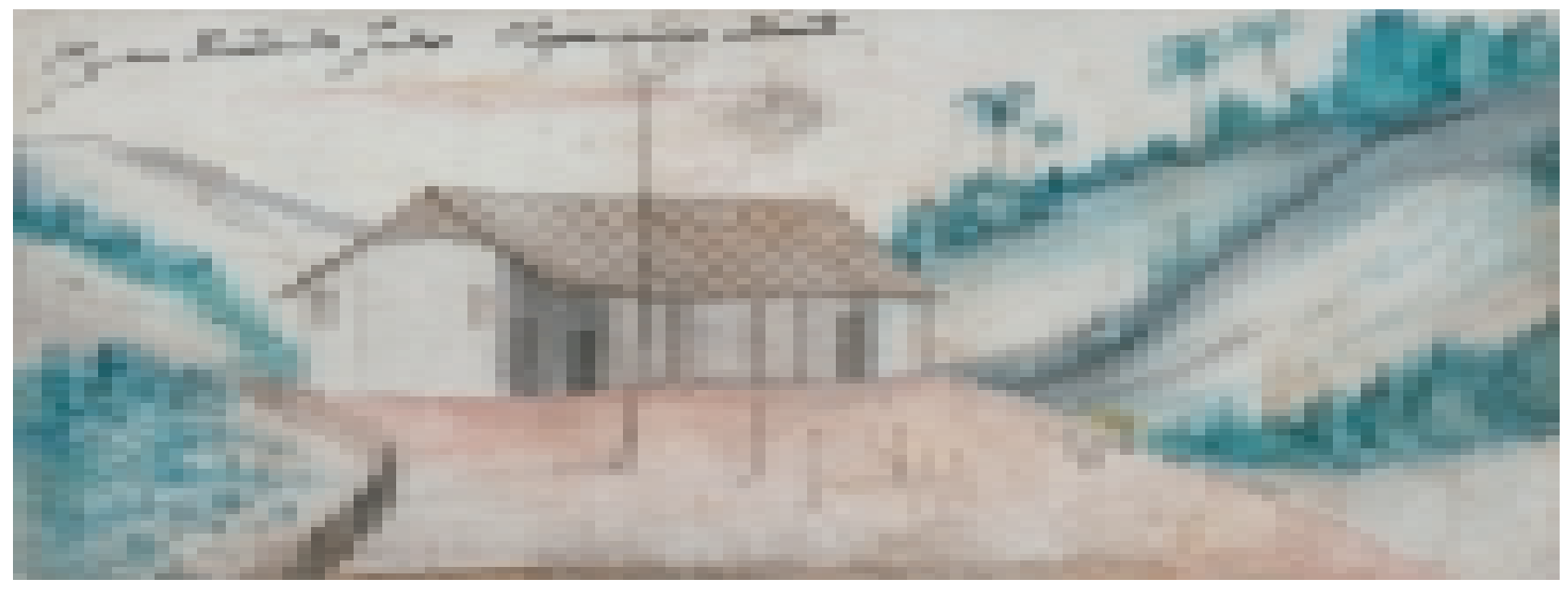




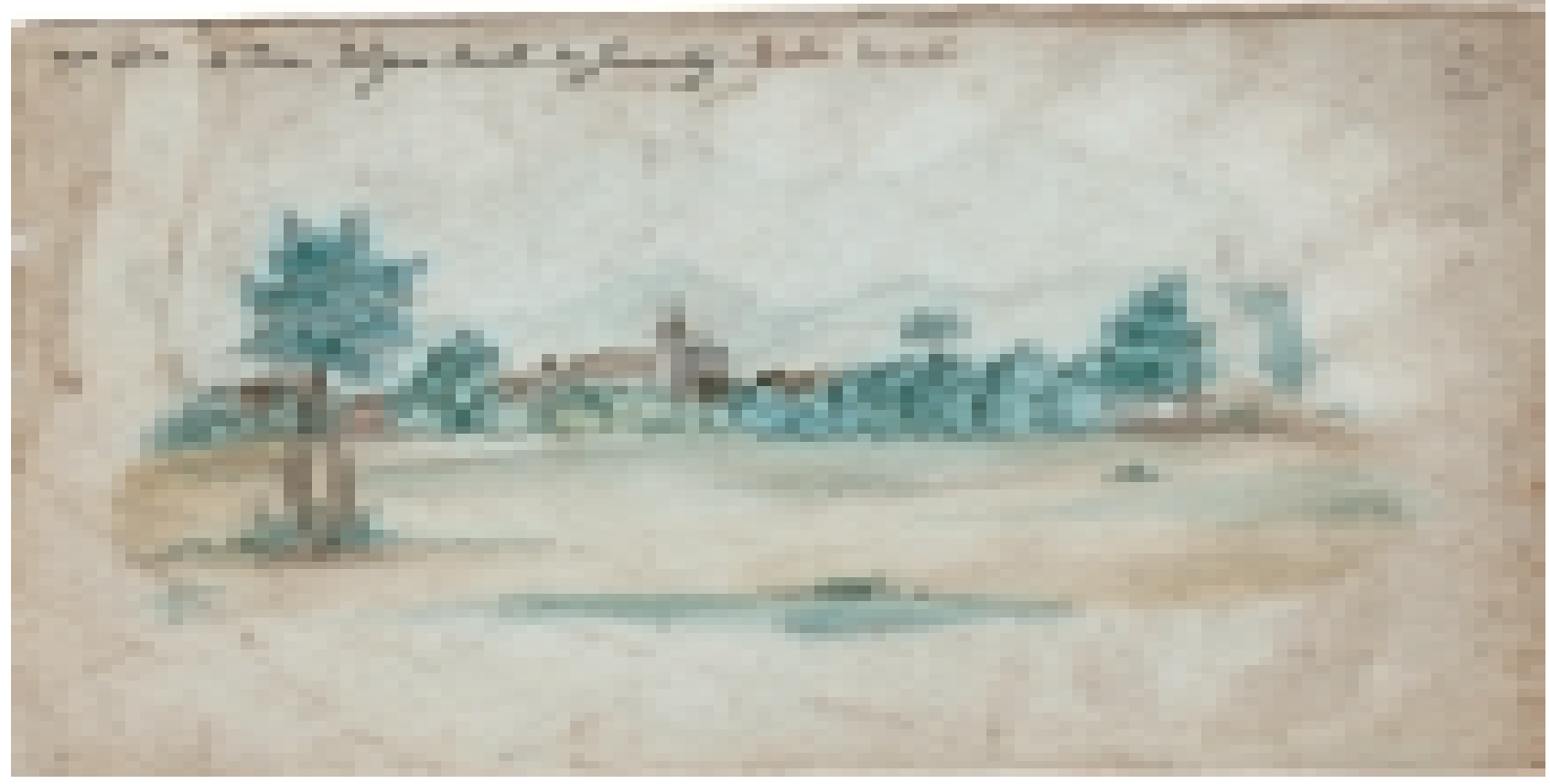
$\mathrm{cm}$. Coleção particular. 
Graças ao cuidado do arquiteto Tommaso Gaudencio Bezzi (1844-1915), em arquivar documentos e inúmeros artigos de jornais relacionados às questões que envolviam diretamente sua pessoa e o Monumento à Independência do Brasil, nos foi possível realizar um resgate de fatos relevantes ao entendimento do edifício-monumento por ele concebido. Muitas descrições de época nos possibilitam visões tanto da representatividade da obra e suas repercussões na sociedade paulistana quanto do trabalho e atividades do arquiteto. Neste sentido o texto reproduz artigos veiculados nos principais jornais de São Paulo e do Rio de Janeiro no final da segunda metade do século XIX. São artigos que descrevem a obra naquele momento histórico e que valorizam a atividade do arquiteto, nos recordando a importância e complexidade da arquitetura como produção artística. "[...] Os alicerces e o pavimento terreo estão já construidos. O tijolo, de contextura homogenea e grande dureza, é trabalhado á $\underline{\text { mão, }}$ fazendo-se nelle, como se fôra ficar a descoberto, todas as molduras com uma perfeição de que só tem o segredo os operarios italianos. Trabalhão na obra cento e tantos operarios, numero que mais tarde deve augmentar, quando a distribuição do serviço o permitir. Um plano inclinado, de grande extenção e movido por vapor, leva os materiaes ao alto do morro. Espera-se que seja o esculptor Bernardelli o encarregado de modelar a estatua de D. Pedro l e as outras que hão de decorar o edificio, que se poderá, dentro em pouco, apreciar pelo modelo em relevo, que esmeradamente está fazendo o Sr. Bezzi."

PALAVRAS-CHAVE: Museu.Arquitetura. São Paulo. Museu Paulista.

Anais do Museu Paulista. São Paulo. N. Sér. v. 10/11.p.127-147 (2002-2003)

The Monument to Independence - Architectural registrations

José Costa de Oliveira Filho

Thanks to the care of the architect Tommaso Gaudencio Bezzi (1844-1915) in filing documents and countless newspaper articles related to the matters that involved himself directly and the Monument to Brazil's Independence, it was possible for us to rescue relevant facts to the understanding of the monument-building conceived by him. Many descriptions of that time enable us to have visions as much of the power of representation of the work and its repercussions on the city São Paulo's society as in the work and activities of the architect.

In this sense the text reproduces articles published in São Paulo and Rio de Janeiro's main newspapers in the end of the second half of the 19th century. The articles describe the work in that historical moment and valorize the architect's activity, reminding us of the importance and complexity of architecture as an artistic production. "[...] The foundations and the ground floor have are already built. The brick of homogen contexture and great hardness is handmade, making on it, as if it was to be uncovered, all the moldings with a perfection whose secret only the ltalian workers have. Hundreds of workers are in the labor, a number that should increase later when the distribution of work allows for that. An inclined plan, of great extension and powered by steam, takes the material to the top of the hill. It is expected that the sculptor Bernadelli is the responsible for moulding the statue of D. Pedro I and the others that shall decorate the building, which should, in a short time, be appreciated by the model in relief, which is carefully making Mr. Bezzi."

KEYWORDS: Museum. Architecture. São Paulo. Museu Paulista.

Anais do Museu Paulista. São Paulo. N. Sér. v. 10/11.p.127-147 (2002-2003).

Obras desconhecidas de Miguelzinho Dutra

Ruth Sprung Tarasantchi

Trata-se da apresentação de catorze aquarelas e Miguelzinho Dutra desconhecidas do público e dos pesquisadores. Estas imagens vêm complementar o repertório de imagens produzidas pelo pintor existentes no Museu Paulista da USP.

PALAVRAS-CHAVE: Coleção. Paisagem. Pintura.

Anais do Museu Paulista. São Paulo. N. Sér. v. 10/11.p.149-166 (2002-2003)

Miguelzinho Dutra's unknown works 
It deals with the presentation of fourteen Miguelzinho Dutra's water-colours unknown to the general public and the researchers. These images come to complement the image repertoire produced by the painter which are at USP's Museu Paulista.

KEYWORDS: Collection. Landscape. Painting.

Anais do Museu Paulista. São Paulo. N. Sér. v. 10/11.p.149-166 (2002-2003)

Ornamentação do Museu Paulista para o Primeiro Centenário: construção de identidade nacional na década de 1920

Miyoko Makino

Nas últimas décadas, vários estudos enfocaram o Museu Paulista, as coleções, o edifício-monumento e a gestão Afonso de Escragnole Taunay, contribuindo para o desenvolvimento do conhecimento histórico e do patrimônio arquitetônico, artístico e cultural de São Paulo. A ornamentação do Museu, organizada por Taunay, para os festejos do Primeiro Centenário da Independência, em 1922, composta essencialmente de pinturas e esculturas, visando narrar o período colonial até a Independência, é o foco deste estudo. As fontes permitem entender o caminho da seleção dos temas, a execução e a disposição das obras, em vários níveis, no Saguão, Escadaria e Salão de Honra. Os anos iniciais da gestão Taunay (1917 - 1945) foram propícios para a execução da ornamentação, visto o apoio oficial e os recursos financeiros obtidos, inclusive da sociedade paulista. A conclusão da ornamentação, no entanto, demorou duas décadas, pela exigüidade de verbas, após as festividades do Centenário. A ornamentação foi dada por concluída por Taunay, com a colocação da última ânfora na Escadaria, em 1931, e a publicação do Guia da Secção Histórica do Museu Paulista, em 1937. No entanto, as últimas pinturas foram feitas e incorporadas nos anos 60 .

PALAVRAS-CHAVE: Museu Paulista. História do Brasil. Iconografia.

Anais do Museu Paulista. São Paulo. N. Sér. v. 10/11.p.167-195 (2002-2003).

Ornamentation of Museu Paulista for the Fist Centennial: construction of national identity in the 1920's

Miyoko Makino

In the last decades, several studies have focused Museu Paulista, the collections, the monument building and Afonso de Escragnole Taunay's term, helping for the development of the historical knowledge and the architectural, artistic and cultural patrimony of São Paulo. The museum's ornamentation, organized by Taunay, for the commemorations of the First Centennial of Independence, in 1922, composed essentially of paintings and sculptures, aiming to narrate the colonial period up to the independence, is the focus of studies. The sources allowed us to understand the way the themes were selected, the making and the disposition of the works, in various levels, in the Hall, the Stairway and the Honour Room. The initial years of Taunay's term (1917 - 1945) were propitious for the making of the ornamentation, given the official support and the financial resources obtained, including the ones from the society of São Paulo. The finalization of the ornamentation, nevertheless, took two decades, due to the exiguity of the income, after the Centennial festivities. The ornamentation was granted as concluded by Taunay, with the placing of the last amphora on the Stairway, in 1931, and the publishing of the Guide of the Historical Section of Museu Paulista (Guia da Secção Histórica do Museu Paulista), in 1937. However, the last paintings were made and incorporated in the 1960's. KEYWORDS: Museu Paulista. History of Brasil. Iconography.

Anais do Museu Paulista. São Paulo. N. Sér.v. 10/11.p.167-195 (2002-2003).

O Sobrado da Convenção em Itu na antiga Rua do Carmo (atual Rua Barão do Itaim): uma pesquisa documental

Anicleide Zequini Rossi

O texto refere-se aos resultados de uma pesquisa documental (inventários post-morten e Livro de Notas) referente a trajetória do edifício em que está instalado o Museu Republicano na Cidade de Itu-SP, extensão do Museu Paulista-USP. Assim, a partir de todas as informações pesquisadas podemos supor que a data de construção do edifício, que abriga o Museu, seja bem anterior a 1850, ano que the tem sido apontado em diversos texto. Este ano registra sim, a presença de uma das famílias moradoras daquele edifício: os Almeida Prado que receberam os Convencionais de 1873.

PALAVRAS-CHAVE: Museu Republicano Convenção de Itu- MP/USP. Itu, História. Itu, Museu. Almeida Prado, Família. 